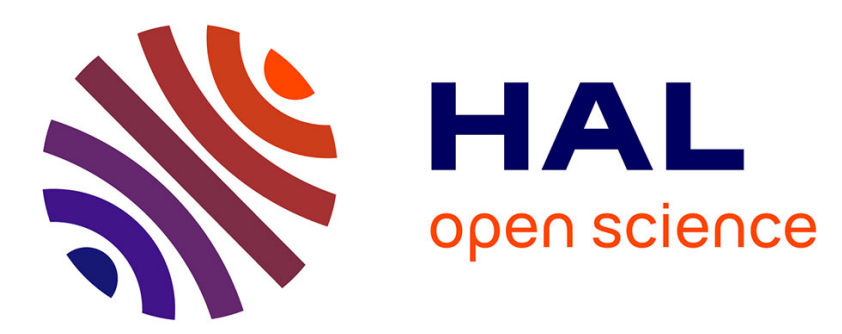

\title{
Impact of four silvicultural systems on birds in the Belgian Ardenne: implications for biodiversity in plantation forests
}

Gaétan Du Bus de Warnaffe, Marc Deconchat

\section{- To cite this version:}

Gaétan Du Bus de Warnaffe, Marc Deconchat. Impact of four silvicultural systems on birds in the Belgian Ardenne: implications for biodiversity in plantation forests. Biodiversity and Conservation, 2008, 107 (5), pp.1041-1055. 10.1007/s10531-008-9364-x . hal-00285573

\section{HAL Id: hal-00285573 \\ https://hal.science/hal-00285573}

Submitted on 5 Jun 2008

HAL is a multi-disciplinary open access archive for the deposit and dissemination of scientific research documents, whether they are published or not. The documents may come from teaching and research institutions in France or abroad, or from public or private research centers.
L'archive ouverte pluridisciplinaire HAL, est destinée au dépôt et à la diffusion de documents scientifiques de niveau recherche, publiés ou non, émanant des établissements d'enseignement et de recherche français ou étrangers, des laboratoires publics ou privés. 
${ }^{1}$ UMR1201 Dynamiques forestières dans l'espace rural, INRA, Chemin de Borde Rouge, BP 52627 F31326 Castanet-tolosan (France). Tél. +33-(0)561.28.53.39 Fax. +33-(0)561.28.54.82 Contact e-mail : marc.deconchat@toulouse.inra.fr ${ }^{2}$ Unité des Eaux et Forêts Université catholique de Louvain Place Croix du Sud 2 bte 9 B 1348 Louvain-la-Neuve (Belgium). 


\section{$1 \quad \underline{\text { Abstract }}$}

2 Uneven-aged management of conifer plantations is proposed as a way to 3 increase the value of these forests for the conservation of bird diversity. To 4 test this assumption, we compared the impact of 4 common silvicultural $5 \quad$ systems on bird communities, defined by cutblock size (large in even-aged silvicultural systems/smaller in uneven-aged silvicultural systems) and tree species composition (spruce/beech) in the Belgian Ardenne where beech forests have been replaced by spruce plantations. The abundances of bird species were surveyed in young, medium-aged and mature stands in three to five forests per silvicultural system (66 plots in all). The effect of silvicultural systems on bird species richness, abundance and composition were analysed both at the plot and at the silvicultural system levels. In plots of a given age, beech stands were richer in species. The composition of bird species at the plot level was explained by stand age and tree composition, but weakly so by stand evenness. For the silvicultural systems, bird species richness was significantly higher in even-aged and in beech forests, and bird species composition depended on the silvicultural system. This study emphasises the importance of maintaining native beech stands for birds and suggests that uneven-aged management of conifer plantations does not provide a valuable improvement of bird diversity comparatively with even-aged systems.

Keywords: Silvicultural system / Biodiversity / Bird communities / Silvicultural cycle / Coniferous plantation. 


\section{$1 \quad$ Introduction}

2 The replacement of native broadleaf stands by uniform conifer plantations is a matter of concern for biodiversity conservation (Lack, 1933; Lack, 1939; Ledant et al., 1983; Laiolo et al., 2004) and this question needs detailed analysis. Bird species composition is affected by tree species composition (e.g. Moss, 1978; Müller, 1987; Bersier \& Meyer, 1994; Bersier \& Meyer, 1995; Hansen, 1995) with few species associated with conifers while some are more associated with broadleaf species. Bird species composition is also influenced by vertical and horizontal vegetation structure that is determined by tree growth in the stand (Wigley \& Roberts, 1997; Lertzmann \& Fall, 1998) and the silviculture (Bellamy et al., 1996; Jokimäki \& Huhta, 1996; Drapeau et al., 2000). The size of the disturbance created by harvesting operations (cutbock size) defines different silvicultural systems and is known to influence biodiversity (Attiwill, 1994; Chesson \& Pantastico-Caldas, 1994; Schnitzer \& Carson, 2001). In most of the cases, planted conifers are managed with large cutblocks ( $>2 \mathrm{ha}$ ) that are considered as unfavorable for bird diversity conservation (Ledant et al., 1983).

To improve the value of planted conifer forests for bird diversity, alternative silvicultural systems based on varying the areas where mature trees are harvested have been proposed (Kerr, 1999). To test this idea, the differences in bird diversity between cutblock sizes in planted conifer forests have to be compared to similar differences in the original broadleaf forests. The Belgian Ardenne has the particularity of containing within a restricted region, four main silvicultural systems, including conifer plantations and broadleaf forest, and both forests managed by small and large cutblocks. In the forest 
1 manager's terminology, the large cutblock sizes are typical of the "evenaged" silvicultural system, while smaller cutblock sizes are typical of the "uneven-aged" silvicultural system used in this part of Europe (Kerr, 1999).

Silvicultural systems have to be characterised by considering the whole silvicultural cycle. Moreover, as biodiversity can be influenced considerably by stand age, the effect of silvicultural systems can only be understood by considering the whole cycle (du Bus de Warnaffe, 2002). Yet the age of the stand should be seen as a stage rather than an absolute age, since the effect of the absolute age on birds depends on the composition of the stand. Three stages can be identified in managed forests: a short one just after logging when low vegetation is dominant, a medium-aged stage when trees grow rapidly and induce a closed canopy, a long mature stage when trees have commercial dimensions and induce a high canopy with an overstorey (du Bus de Warnaffe \& Lebrun, 2004). An over-mature stage with collapsing and senescent trees can be identified in forests where harvesting does not occur (Fuller \& Moreton, 1987). Different silvicultural systems can be compared for each stage, or by gathering the stages over space, using a space-for-time substitution. Two spatial levels must therefore be considered: the plot, which only considers one stage, and a larger spatial and temporal scale integrating the complete silvicultural cycle of a silvicultural system (Huston, 1999).

The hypothesis tested in this paper is that uneven-aged conifer planted forests have a higher value for bird conservation than even-aged conifer planted forests. This difference was tested with a sampling design including several stages of forest development and was compared with the same design in natural beech forests. These comparisons help to identify the impacts on 
1 biodiversity of the silvicultural systems applied to a large part of the forests in

2 Europe and may provide guidance to mitigate their consequences on

3 biodiversity conservation.

\section{$4 \quad$ Materials and methods}

\section{$5 \quad$ Study region}

6 The study was conducted in the Belgian Ardenne, between Namur and

7 Luxembourg (Figure 1). The historical land-use types in this region are

8 pastures and broadleaf woodlands, which now account for $20 \%$ and $40 \%$ of

9 the region (Paquet et al., 2006). They have been partly transformed into commercial conifer plantations $(30 \%$ of the area) over the last 150 years

11 (Devillez \& Delhaise, 1991). The elevation of our study plots ranged from 12320 to $560 \mathrm{~m}$, mean annual rainfall from 1050 to $1200 \mathrm{~mm} \cdot \mathrm{yr}^{-1}$ and mean annual temperatures from 7.3 to $7.8^{\circ} \mathrm{C}$ (Weissen et al., 1994). All study plots comprised plantations established on Luzulo-Fagetum or Luzulo-Quercetum vegetation types, according to Noirfalise (1984) and Rameau et al. (2000) phytosociological systems, on flat or very gently sloping ground with acid and moderately dry soils (Dystric cambisol) (FAO, 1990). The main tree species are native, mostly Norway spruce (Picea abies (L.) Karst), beech (Fagus sylvatica L.) and oaks (Quercus petraea (Mattme.) Liebl. and Quercus robur L.), with few introduced species, mostly Douglas fir (Pseudotsuga menziesii (Mirb.) Franco). Rotation length is typically 60 to 80 years for spruce, which is usually planted, and 120 to 150 years for beech, which is usually natural. Logging is done by clearcut on cutblocks with sizes ranging from 0.1 ha to more than 2 ha. 
1 In even-aged systems, all the tree of a stand ( $>1$ ha) are of the same age at a

2 given time, in this system, logging is applied on large areas (cutblocks) by

3 clearcutting. Even-aged systems result from planted forests for conifer tree

4 and for beech tree from naturally regenerated forests managed to produce

5 timber wood. In uneven-aged systems, the trees of different ages are mixed

6 on smaller areas $(<0.5$ ha), logging is done by cutting mature trees on small

7 cutblocks, as younger trees remain we do not be considered it as a clearcut.

8 Uneven-aged conifer silvicultural system has developed from even-aged

9 planted forests where small logging areas have been used rather than the large

10 typical clearcuts. Forest managers consider it as a way to improve the

11 sustainability of planted conifer forests.

13 Sampling design

14 The study compared four important silvicultural systems in the Belgian 15 Ardenne :

16 1) even-aged conifer (EC): planted forests with greater than $80 \%$ cover of

17 Norway spruce logged by clearcut on large cutblocks ( $>2 \mathrm{ha})$;

182 2) even-aged Beech (EB): naturally regenerated forests with greater than $80 \%$

19 cover of Beech logged by clearcut on large cutblocks ( $>2 \mathrm{ha})$;

203 ) uneven-aged conifer (UC): planted forests with greater than $80 \%$ cover of

21 Norway spruce logged on small cutblocks $(<0.5 \mathrm{ha})$ producing a mix of trees

22 of different ages;

23 4) uneven-aged Beech (UB): naturally regenerated forests with greater than

$24 \quad 80 \%$ of Beech logged by small cutblocks $(<0.5$ ha $)$. 
1 We selected three to six forests per silvicultural system, these forests

2 comprised at least 15 ha corresponding to the silvicultural system as defined

3 above and managed for at least two rotations with the same system (Du Bus

4 de Warnaffe \& Dufrêne, 2004). The size of the cutblocks and the composition

5 of each forest were determined by GIS analysis of $1 / 10.000$ aerial

6 photographs, and checked on site.

7 Plots were selected in three non-overlapping stages covering the silvicultural cycles of each silvicultural system (Fuller \& Moreton, 1987; Hansen, 1995; Lertzmann \& Fall, 1998): regeneration stage (stage 1: trees 3-10 years old), medium-aged stage (stage 2: 20-40 years old for conifer, 30-60 years old for beech), and mature stage (stage 3: 50-80 years old for conifer, 80-140 years old for beech). The stage in uneven-aged systems was defined according to the time since the last logging, it is similar to the age of the oldest trees at a given time. The plots were separated by at least $200 \mathrm{~m}$. A set of three plots belonging to these three stages in the same forest and the same silvicultural system defined a silvicultual cycle since it included the tree stages (Figure 2).

The sampling was thus characterised by 54 plots belonging to 18 silvicultural systems (Table $1 \& 2$ ).

\section{Bird data}

The bird survey method was based on point counts (Bibby et al., 1985; Frochot \& Roché, 1990; Petty \& Avery, 1990) within a maximum 25 m fixed radius visually estimated. Singing birds were surveyed by trained observers over 20 minute periods in each plot, twice during the breeding season (April and early June 2000), to record both sedentary and migrant species, and to 
1 reduce the bias associated with differences in detectability. The data were

2 collected in the first four hours after dawn, avoiding rainy and windy days.

3 According to the territorial behavior of most of the bird species in spring, the

4 fixed radius of the plots and the experience of the surveyors, we assumed to

5 have comparable lists, but not necessarily exhaustive, of the bird species

6 living in the plots (Buckland et al., 2001; Kery \& Schmid, 2004). All

7 recorded species were used for the analyses, except over-flying birds, such as

8 raptors and corvids, which were discarded. The abundance was estimated as two individuals (a pair) for each bird heard singing and one individual for sum of the abundance index in the three plots (stages 1,2 and 3).

\section{Data analysis}

ANOVA was used to test for differences in species richness and abundance 
1 allowing us "to describe the strongest patterns in species composition"

2 (McCune \& Grace, 2002). The result is an ordination of the species and the samples along axes computed as the solution of linear equations linking (1) the species space, where each sample is a coordinate, and (2) the sample space, where each species is a coordinate. Correspondence analysis can be interpreted as a summary of the departure of the observed contingency table (species by sample) from a null hypothesis of independence between species and samples, estimated by the $C h i^{2}$ distance (Couteron et al., 2003). Several orthogonal axes can be computed and can be interpreted as follow: the closer 
1 the separation of the sample classes is maximised according to their species

2 composition (Thioulouse et al., 1997). A permutation test measured the

3 departure of the observed structure from a random distribution of the species

4 and gave a significance level of the difference between groups. All

5 calculations were performed with $\mathrm{R}$ software ( $\mathrm{R}$ development core team,

6 2006) and with ade4 package (Chessel et al., 2004).

$7 \quad \underline{\text { Results }}$

8 A total of 44 species were found but 10 were recorded only once. The most

9 abundant species were Chaffinch (Fringilla coelebs), Robin (Erithacus

10 rubecula), Wren (Troglodytes troglodytes), and Wood pigeon (Columba

11 palumbus) (Table 3).

\section{Species richness and abundance}

Plot analysis (each stage)

We found 3 to 20 species per plot. Tree species composition was the only factor with a significant effect on bird species richness $(\mathrm{F}=10.8353 ; \mathrm{df}=1$; $\mathrm{p}=0.0020)$. The mean species richness in beech plots $(14.12 \pm 4.38 ; \mathrm{n}=24)$ was higher than in conifer plots $(10.50 \pm 3.59 ; n=30)$. The variability of the species richness was higher in beech plots than in conifer plots (Figure 3). In beech plots, the mean species richness of small cutblocks size (uneven-aged system) only these two stages, uneven-aged plots had higher bird species richness than in even-aged plots, the few cases with extremely low values may explain 
1 why these differences were not significant. In conifer plots, no particular

2 differences were identified between species richness according to cutblock

3 size and stage.

Total bird abundance was highly correlated to species richness $\left(r^{2}=0.86\right.$, $\mathrm{p}<0.001$ ). As for bird species richness, tree species composition was the only factor explaining a significant part of bird abundance variability $(F=7.4354$ $\mathrm{df}=1 ; \mathrm{p}=0.0092) ;$ the highest mean abundance was in beech plots $(21.46 \pm 7.75 ; n=24)$, the lowest in conifer plots $(16.03 \pm 6.31 ; n=30)$ (Figure 3$)$ In conifer plots, no clear pattern was observed for abundance, nor for species richness. In beech plots, on the other hand, the pattern was different. In evenaged plots, mature stands had clearly a higher abundance (but few samples with extremely low values) than younger stages. Conversely, the highest value was for first stage in uneven-aged plots, but with lower differences with the other stages comparatively with even-aged plots.

\section{Silvicultural system analysis (stages $1+2+3$ pooled together)}

We found 12 to 27 species in the silvicultural systems. Cutblock size $(\mathrm{F}=6.8983 ; \mathrm{df}=1 ; \mathrm{p}=0.0176)$ and tree composition $(\mathrm{F}=4.7767 ; \mathrm{df}=1$; $\mathrm{p}=0.0431)$ significantly explained bird species richness variability, with the highest bird species richness in even-aged beech forests $(24.67 \pm 2.08 ; n=3)$ and the lowest in uneven-aged conifer forests $(16.33 \pm 4.88 ; n=6)$ (Figure 4). The difference of bird species richness between beech and conifer was higher in uneven-aged forests than in even-aged ones. No factor explained a significant part of bird species abundance, however, it can be noticed that in beech forests, the abundance was higher in uneven-aged forests than in evenaged, while the differences were less visible in conifer forests (Figure 4). 
2

\section{Plot analysis}

The first stages of the even-aged silvicultural systems were significantly $(p<0.001)$ separated from the others groups along the first axis of the between group analysis (Figure 5). The beech plots and the conifer plots of the older stages were separated along the second axis, but the even-aged and unevenaged plots in these groups were not separated. Sylvia communis, Emberiza citrinella and Carduelis cannabina were positively associated with even-aged first stage plots, while Regulus species and Nucifraga caryocatactes were positively associated with coniferous plots. No particular species seemed to be associated with the beech plots, since most of the species close to the position of these plots were close to the origin of the factorial plan and thus were common in most of the samples (Figure 5).

\section{Silvicultural systems analysis}

Conifer plots were separated $(p<0.001)$ from the other ones on the first axis of the between group analysis (Figure 6). Even-aged beech forests were separated from the other groups on the second axis, with a lower variability of their composition (distribution along axes). Cutblock size showed a significant effect $(\mathrm{p}<0.001)$ in beech forests. Regulus species, Nucifraga caryocactactes, Sylvia communis and Carduelis carduelis were associated with the coniferous forests; Dendrocopos minor, Saxicola torquata and Picus canus were associated with the even-aged beech, Dendrocopos medius was associated with uneven-aged beech forests. 


\section{$1 \quad$ Discussion}

2 Stand composition: conifer vs beech

3 Although some studies have identified little impact of tree species 4 composition on bird communities (Müller, 1987; Patterson et al., 1995; 5 Donald et al., 1998), most authors have found, as we have, a greater diversity 6 in broadleaf forests compared with coniferous forests of similar stages, at plot $7 \quad$ level (Moss, 1978; James \& Warmer, 1982; Bibby et al., 1985; Lebreton et al., 1987; Lebreton \& Choisy, 1991; Baguette et al., 1994; Solonen, 1996;

$9 \quad$ Gjerde \& Saetersdal, 1997) as well at larger levels including the whole silvicultural cycle (Jokimäki \& Huhta, 1996; Drapeau et al., 2000). Conifer 
aged systems, whatever the tree composition, was different from the other stages (Figure 5). The species more associated to first stages of even-aged forests were mainly species known to be able to live in open habitats, having adapted to the practice of large clear-cuts (Paquet et al., 2006), while smaller logged areas in uneven-aged forests seem to have fewer associated species Paquet et al. (2006) demonstrated that the species associated to the open areas in forest are not intermediate between the typical bird communities from agricultural habitat and forests, but were "specific" and contributed to $38.6 \%$ to the conservation value in large open areas.

These results do not confirm the main hypothesis of the paper, that unevenaged management of planted conifer forests improves their bird conservation value. However, this conclusion should be moderated by the spatial dimension of even-aged and uneven-aged silvicultural systems, which has not been taken into account in this study (Picket et al., 1989; Kotliar \& Wiens, 1990). Even-aged system produces a coarser grain spatial pattern of heterogeneity than uneven-aged systems, with larger patches of even-aged trees. This induces edge-effects that may also have an influence on bird species distribution (Deconchat \& Balent, 2001).

\section{Stand age: Bird diversity according to silvicultural stages}

Bird species composition in even-aged stage 1, i.e. large cutblocks, had a sharp contrast with stage 2 and 3 . It was characterised by species known to be associated with open habitat conditions (Haila et al., 1980; Fuller \& Moreton, 1987; Baguette et al., 1994; Jacob, 1996). Though Bibby et al. (1985) suggested that very few species require large clear-cuts, a number of species preferred even-aged stage 1 as it has been already noticed by Paquet et al. 
1 (2006). We were surprised not to obtain a higher species richness in stage 1

2 than in stages 2 and 3, as did a number of authors (Müller, 1987; Bersier \&

3 Meyer, 1994, Patterson et al., 1995; Jokimäki \& Huhta, 1996; Fuller \&

4 Green, 1998). Indeed, species richness can greatly vary in young stands in

5 plantations (Frochot, 1971; Bibby et al., 1985), as well as in natural forest,

6 even under strong disturbances such as coppice clear-cuts (Deconchat \&

$7 \quad$ Balent, 2001).

8 Some authors have identified differences in bird communities between

9 medium-aged and mature stands (Fuller \& Moreton, 1987; Lebreton \& Pont,

10 1987) with some bird species associated with old and senescent trees. We did

11 not identify such a pattern, probably because of the intensive silviculture

12 practised in the Ardenne, based on short rotations, high densities and

13 systematic removal of diseased and dead trees. At stage 3 in our study area,

14 trees were not very large (Table 2), and hollow or dead trees were rare, which

15 makes a difference with the same stage observed in less intensive contexts.

\section{Conclusion}

17 The results confirm the strong impact of tree species composition on bird 18 species richness, abundance and composition. In the Belgian Ardenne, the 19 massive introduction of spruce plantations has allowed some new species to breed (e.g. Nucifraga caryocatactes) but their bird diversity is clearly of lower conservation value than in the beech forests they have supplanted (Ledant et al., 1983). The conversion of even-aged conifer plantations to uneven-aged management (Schütz, 2001), which has been proposed as a way to improve biodiversity in conifer forests, does not seem to improve their ability to shelter richer or more diverse bird community than in even-aged 
1 plantations. Even-aged management in beech forest was suspected to have

2 negative impacts on biodiversity (Paquet et al., 2006). This opinion is not

3 supported by the results of our study. We observed that the first stage after

4 clear-felling on large zones seemed to offer temporary habitats for species

5 also inhabiting fallow areas and extensive meadows (Delvaux, 1998; Paquet

6 et al., 2006), and species richness and composition do not differ much in

7 simple (even-aged) and more complex (uneven-aged) canopies of the same $8 \quad$ age (stage 2 or 3 ).

\section{$\underline{\text { Acknowledgements }}$}

11 We are most grateful to J.P. Jacob and his team for the bird sampling, to $\mathrm{Ph}$.

12 Lebreton for methodological and scientific advice, to the Ministry of the

13 Walloon Region for their financial support for the project and finally, to all

14 the field engineers and technicians (DNF) who allowed us to carry out this

15 study. H. Thomas and J. Willm helped to improve the manuscript. We thank

16 the reviewers of a first version of this paper.

\section{$\underline{\text { References }}$}

Attiwill MP (1994) The disturbance of forest ecosystems: the ecological basis for conservative management. Forest Ecol Manage 63:247-300.

Baguette M, Deceuninck B, Muller Y (1994) Effects of spruce afforestation on bird community dynamics in a native broadleaved forest area. Acta Oecol, Oecol Gen 15(3):275-288

Balent G, Courtiade C (1992) Modelling bird communities/landscape patterns 
relationships in a rural area of South-Western France. Landscape Ecol 6(3):195-211.

Bellamy PE, Shelley A, Hinsley A, Newton I (1996) Factors influencing bird species numbers in small woods in south-east England. J Appl Ecol $33: 249-262$

Bersier LF, Meyer DR (1994) Bird assemblages in mosaic forests - the relative importance of vegetation structure and floristic composition along the successional gradient. Acta Oecol, Oecol Gen 15:561-576.

Bersier LF, Meyer DR (1995) Relationships between bird assemblages, vegetation structure and floristic composition of mosaic patches in riparian forests. Rev Ecol 50:15-32.

Bibby CJ, Phillips B, Sedon JE (1985) Birds of restocked conifer plantations in Wales. J Appl Ecol 22:619-633.

Buckland ST, Anderson DR, Burnham KL, Laake JL, Borchers DL, Thomas L. (2001) Introduction to distance sampling, Oxford University Press; Oxford, UK. 432 pages.

Chessel D, Dufour A-B, Thioulouse J (2004) The ade4 package-I- One-table methods. R News 4:5-10.

Chesson P, Pantastico-Caldas M (1994) The forest architecture hypothesis for diversity maintenance. Trends Ecol Evol 9(3):79-80.

Couteron P, Pelissier R, Mapaga D, Molino J-F, Teillier L (2003) Drawing ecological insights from a management-oriented forest inventory in French Guiana. Forest Ecology \& Management 172 (1):89-108. 
1 Deconchat M, Balent G (2001) Vegetation and bird community dynamics in fragmented coppice forests. Forestry 74(2):105-118.

Delvaux A (1998) Espèces sensibles cherchent mise à blanc d'accueil. Forêt Wallonne 34:11-17.

Devillez F, Delhaise C (1991) Histoire de la forêt wallonne. Forêt Wallonne $13: 2-12$.

Donald PF, Fuller RJ, Evans AD, Gough SJ (1998) Effects of forest management and grazing on breeding bird communities in plantations of broadleaved and coniferous trees in western England. Biol Conserv 85: 183-197

Drapeau P, Leduc A, Giroux JF, Savard JPL, Bergeron Y, Vickery WL (2000) Landscape-scale disturbance and changes in bird communities of boreal mixed-wood forests. Ecol Monogr 70(3):423-444.

du Bus de Warnaffe G (2002) Impact des systèmes sylvicoles sur la biodiversité : une approche comparative en Ardenne - Réaction de la flore vasculaire, des coléoptères carabidés et de l'avifaune chanteuse à la structure de l'habitat forestier, à plusieurs échelles spatiales. Doctoral thesis, University of Louvain, Belgium. 132 pp.

du Bus de Warnaffe G, Dufrêne M (2004) To what extent can management variables explain species assemblages? A study with carabid beetles in forests. Ecography 27(6) :701-714

du Bus de Warnaffe, G. \& Lebrun, P. (2004): Effects of forest management on carabid beetles in Southern Belgium: implications for biodiversity conservation. Biological Conservation 118(2): 219-234. 
1 Duchiron MS (1994) Gestion des futaies irrégulières et mélangées. Author's edition, Nancy and Paris.

FAO 1990. FAO-Unesco soil map of the world. Revisited legend. Soils bulletin 60, FAO, Rome, 119 p.

Frochot B (1971) Ecologie des oiseaux forestiers de Bourgogne et du Jura. Doctoral thesis, University of Dijon, France - CNRS Document A. 0.5264 .

Frochot B, Roché J 1990. Suivi de populations d'oiseaux nicheurs par la méthode des indices ponctuels d'abondance IPA. Alauda 58:29-35.

Fuller RJ, Moreton BD (1987) Breeding bird populations of kentish sweet chestnut (Castanea sativa) coppice in relation to age and structure of the coppice. J Appl Ecol 24:13-27

Fuller RJ, Green GH (1998) Effects of woodland structure on breeding bird populations in stands of coppiced lime Tilia cordata) in western England over a 10-year period. Forestry 71:199-217.

Gjerde I, Saetersdal M (1997) Effects on avian diversity of introducing spruce plantations in the native pine forests of western Norway. Biol Conserv 79: $241-250$.

Haila Y, Järvinen O, Väisänen RA (1980) Effects of changing forest structure on long-term trends in bird populations in SW Finland. Ornis Scand $11: 12-22$

Hansen AJ (1995) Bird habitat relationships in natural and managed forests in the West Cascades of Oregon. Ecol Applic 5(3):555-569. 
1 Hill MO (1974) Correspondence analysis: a neglected multivariate method. Appl Stat 23:340-354.

Huston MA (1999) Local processes and regional patterns: appropriate scales for understanding variation in the diversity of plants and animals. Oikos 86:393-401.

Jacob JP (1996) Avifaune nicheuse de clairières en forêt de Soignes. Aves 33:221-228.

James FC, Wamer NO (1982) Relationships between temperate forest bird communities and vegetation structure. Ecology 63:159-171.

Jokimäki J, Huhta E (1996) Effects of landscape matrix and habitat structure on a bird community in northern Finland: a multi-scale approach. Ornis Fenn 73:97-113.

Kerr G (1999) The use of silvicultural systems to enhance the biological diversity of plantation forests in Britain. Forestry 72:191-205.

Kery M, Schmid H (2004) Monitoring programs need to take into account imperfect species detectability. Basic and Applied Ecology 5 (1):65-73.

Kirk D, Hobson KA (2001) Bird-habitat relationships in jackpine boreal forests. Biol Conserv 147:217-143.

Kotliar NB, Wiens JA (1990) Multiple scales of patchiness and patch structure a hierarchical framework for the study of heterogeneity. Oikos 59(2):253-260.

Lack D (1933) Habitat selection in birds with special reference to the effects of afforestation on the Breckland avifauna. J Anim Ecol 2:239-262. 
Lack D (1939) Further changes in the Breckland avifauna caused by afforestation. J Anim Ecol 8:277-285.

Laiolo P, Caprio E, Rolando A (2004) Can forest management have seasondependent effects on bird diversity? Biodiversity \& Conservation 13(10): 1925-1941,

Lebreton Ph, Broyer J, Pont B (1987) Avifaune et altérations forestières II: L'avifaune des boisements résineux du Haut-Baujolais ; relations structurales végétation-avifaune (with english summary). Revue d'Ecologie 4:71-81.

Lebreton Ph, Pont B (1987) Avifaune et altérations forestières I: l'avifaune des boisements résineux du Haut-Beaujolais, considérations générales (with english summary). Acta Oecol, Oecol Gen 8:227-235.

Lebreton Ph, Choisy JP (1991) Avifaune et altérations forestières III: Incidences des aménagements forestières - substitutions Quercus/Pinus en milieu subméditerranéen (with english summary). Ecologie 22:213220.

Ledant J-P, Jacob J-P \& Devillers, P (1983). Protégeons nos oiseaux. Animaux menacés en Wallonie. Région Wallonne, Jambes; Duculot, Gembloux: 325 pp

Lertzman K, Fall J (1998) From forest stand to landscape: spatial scale and the roles of disturbances. In: Peterson L, Parker VT (eds.) Ecological scale, theory and applications. Complexity in ecological systems, Columbia University Press, New York, p 339-367.

Lopez G, Moro MJ (1997) Birds of Aleppo pine plantations in south-east 
Spain in relation to vegetation composition and structure. Ecology $34: 1257-1272$.

McCune B, Grace JB (2002) Analysis of ecological communities, Gleden beach, Oregon:MjM Software Design, 300 pages.

Moss B (1978) Diversity of woodland song-bird populations. J Anim Ecol $47: 521-527$

Müller Y (1987) L'avifaune nicheuse des deux successions écologiques du pin sylvestre et du hêtre dans les Vosges du Nord (with english summary). Acta Ecol, Oecol Gen 8:185-189.

Noirfalise A (1984) Les stations forestières de Belgique. Presses agronomiques de Gembloux, Belgium. 235p.

Paquet JY, Vandevyvre X, Delahaye L, Rondeux J (2006) Bird assemblages in a mixed woodland-farmland landscape: The conservation value of silviculture-dependant open areas in plantation forest. Forest Ecol Manage 227 (1-2):59-70.

Patterson IJ, Ollason JG, Doyle P (1995) Bird populations in uplands spruce plantations in northern Britain. Forest Ecol Manage 79:107-131.

Pelissier R, Couteron P, Dray S, Sabatier D. (2003) Consistency between ordination techniques and diversity measurements: Two strategies for species occurrence data. Ecology 84 (1):242-251.

Petty SJ, Avery MI (1990) Bird census methods and techniques. In: Forest Bird Communities. A review of the ecology and management of forest bird communities in relation to silviculture practices in the British uplands. Forestry Commission, Edinburgh, pp. 12-16. 
Picket STA, Kolasa J, Armesto JJ, Collins SL (1989) The ecological concept of disturbance and its expression at various hierarchical levels. Oikos $54: 129-136$

R Development Core Team. 2006. R: A language and environment for statistical computing. R Foundation for Statistical Computing, Vienna, Austria. ISBN 3-900051-07-0, URL http://www.R-project.org.

Rameau JC, Gauberville C, Drapier N (2000) Gestion forestière et biodiversité. Identification et gestion intégrée des habitats et espèces d'intérêt communautaire, partie Wallonie et Grand-Duché de Luxembourg. ENGREF, ONF \& IDF, Paris.

Schnitzer AS, Carson WP (2001) Treefall gaps and the maintenance of species diversity in a tropical forest. Ecology 82(4):913-191.

Schütz JP (2001) Opportunities and strategies of transforming regular forests to irregular forests. Forest Ecol Manage 151:87-94.

Sokal RR, Rohlf FJ (2000) Biometry, the principles and practice of statistics in biological research (third edition). WH Freeman \& co, New York, 887 $\mathrm{p}$.

Solonen T (1996) Patterns and variations in the structure of forest bird communities in southern Finland. Ornis Fenn 73 12-26.

Thioulouse J, Chessel D, Dolédec S, Olivier JM (1997) ADE-4: Multivariate analysis and graphic display software Stat Comp 7:75-83.

Weissen F, Bronchart L, Piret A (1994) Fichier écologique des essences et Guide de boisement des stations forestières de Wallonie. Groupe interuniversitaire « définition de l'aptitude des stations », FSAGx-UCL-ULB- 
2 Wigley TB, Roberts TH (1997) Landscape-level effects of forest management on faunal diversity in bottomland hardwoods. Forest Ecol Manage 90:141-154. 
1 Du Bus de Warnaffe, G. - Table 1

2

3

\begin{tabular}{cccccc} 
Silvicultural system & EC & EB & UC & UB & Total \\
\hline Number of plots: in stage 1 & 4 & 3 & 6 & 5 & 18 \\
in stage 2 & 4 & 3 & 6 & 5 & 18 \\
in stage 3 & 4 & 3 & 6 & 5 & 18 \\
\hline Total number of plots & 12 & 9 & 18 & 15 & 54 \\
\hline
\end{tabular}

7 Table 1. Number of plots. Silvicultural systems are defined by cutblock

8 size and tree species composition of the forest: $\mathrm{EC}=$ Even-aged Conifer;

$9 \quad \mathrm{~EB}=$ Even-aged Beech; $\mathrm{UC}=$ Uneven-aged Conifer; $\mathrm{UB}=$ Uneven-aged

10 Beech. Each silvicultural system contains 3 stages. See text and Figure 2

11 for details.

12 
Du Bus de Warnaffe, G. - Table 2

\begin{tabular}{lllcccc}
$\begin{array}{l}\text { Silvicultural } \\
\text { system }\end{array}$ & Stage & Tree species & $\begin{array}{c}\text { Altitude } \\
(\mathbf{m})\end{array}$ & $\begin{array}{c}\text { Mean dbh } \\
\mathbf{( c m )}\end{array}$ & $\begin{array}{c}\text { Basal area } \\
\left(\mathbf{m}^{2} / \mathbf{h a}\right)\end{array}$ & $\begin{array}{c}\text { Cutblock } \\
\text { size (ha) }\end{array}$ \\
\hline EC & $\mathbf{1}$ & PA & $380-520$ & $2-7$ & $1-7$ & $4-12$ \\
& $\mathbf{2}$ & PA, PM & $320-490$ & $20-27$ & $34-41$ & - \\
& $\mathbf{3}$ & PA, PM & $320-520$ & $43-50$ & $47-53$ & - \\
\hline EB & $\mathbf{1}$ & FS & $410-540$ & $2-6$ & $1-5$ & $3-6$ \\
& $\mathbf{2}$ & FS & $380-540$ & $28-44$ & $21-31$ & - \\
& $\mathbf{3}$ & FS & $380-460$ & $43-59$ & $22-28$ & - \\
\hline UC & $\mathbf{1}$ & PA, PM & $420-580$ & $2-8$ & $18-27$ & $0.02-0.45$ \\
& $\mathbf{2}$ & PA, PM & $420-580$ & $22-36$ & $32-40$ & - \\
& $\mathbf{3}$ & PA, PM & $420-580$ & $41-52$ & $31-42$ & - \\
\hline UB & $\mathbf{1}$ & FS (+ QP, QR) & $410-500$ & $1-8$ & $11-20$ & $0.03-0.25$ \\
& $\mathbf{2}$ & FS & $350-500$ & $23-33$ & $17-28$ & - \\
& $\mathbf{3}$ & FS (+ QP, QR) & $350-500$ & $34-52$ & $21-29$ & - \\
\hline
\end{tabular}

Table 2. Major characteristics of plots in each class (see Table 1 for codes). All plots were situated on flat or very slightly sloping ground, on acid brown and moderately dry soils. Dbh (diameter at breast height) and basal area were measured on 0.20 ha. Cutblock size was measured for stage 1. Tree species : $\mathrm{PA}=$ Picea abies $; \mathrm{PM}=$ Pseudotsuga menziesii $; \mathrm{FS}=$ Fagus sylvatica $; \mathrm{QP}=$ Quercus petraea $; \mathrm{QR}=$ Quercus robur . 
1 Du Bus de Warnaffe, G. - Table 3

\begin{tabular}{|c|c|c|c|c|c|c|c|c|}
\hline \multirow[b]{2}{*}{ Code } & \multirow[b]{2}{*}{ Scientific name } & \multicolumn{5}{|c|}{ Beech } & \multirow{2}{*}{ Conifer } & \multirow[t]{2}{*}{ Total } \\
\hline & & $\begin{array}{l}\text { Beech } \\
\text { Even- } \\
\text { aged }\end{array}$ & $\begin{array}{l}\text { Beech } \\
\text { Uneven } \\
\text {-aged }\end{array}$ & & $\begin{array}{l}\text { Conifer } \\
\text { Even- } \\
\text { aged }\end{array}$ & $\begin{array}{c}\text { Conifer } \\
\text { Uneven } \\
\text {-aged }\end{array}$ & & \\
\hline ACAU & Carduelis cannabina & 0 & 0 & 0 & 0 & 1 & 1 & 1 \\
\hline ATRI & Anthus trivialis & 3 & 1 & 4 & 2 & 0 & 2 & 6 \\
\hline CBRA & Certhia brachydactyla & 1 & 4 & 5 & 0 & 1 & 1 & 6 \\
\hline CCAN & Cuculus canorus & 2 & 1 & 3 & 4 & 0 & 4 & 7 \\
\hline CCAR & Carduelis carduelis & 0 & 0 & 0 & 1 & 1 & 2 & 2 \\
\hline CCOC & $\begin{array}{l}\text { Coccothraustes } \\
\text { coccothraustes }\end{array}$ & 1 & 4 & 5 & 2 & 0 & 2 & 7 \\
\hline CFAM & Certhia familiaris & 0 & 2 & 2 & 0 & 4 & 4 & 6 \\
\hline CPAL & Columba palumbus & 3 & 4 & 7 & 3 & 4 & 7 & 14 \\
\hline CSPI & Carduelis spinus & 0 & 0 & 0 & 0 & 0 & 0 & 0 \\
\hline DMAJ & Dendrocopos major & 3 & 5 & 8 & 0 & 4 & 4 & 12 \\
\hline DMAR & Dryocopus martius & 3 & 3 & 6 & 0 & 1 & 1 & 7 \\
\hline DMED & Dendrocopos medius & 0 & 3 & 3 & 0 & 0 & 0 & 3 \\
\hline DMIN & Dendrocopos minor & 1 & 0 & 1 & 0 & 0 & 0 & 1 \\
\hline ECIT & Emberiza citrinella & 1 & 0 & 1 & 1 & 0 & 1 & 2 \\
\hline ERUB & Erithacus rubecula & 3 & 5 & 8 & 4 & 6 & 10 & 18 \\
\hline FCOE & Fringilla coelebs & 3 & 5 & 8 & 4 & 6 & 10 & 18 \\
\hline GGLA & Garrulus glandarius & 2 & 5 & 7 & 2 & 5 & 7 & 14 \\
\hline LCUR & Loxia curvirostra & 1 & 0 & 1 & 1 & 1 & 2 & 3 \\
\hline NCAR & Nucifraga caryocatactes & 0 & 0 & 0 & 1 & 0 & 1 & 1 \\
\hline PATE & Parus ater & 3 & 2 & 5 & 4 & 5 & 9 & 14 \\
\hline PCAE & Parus caeruleus & 1 & 5 & 6 & 0 & 2 & 2 & 8 \\
\hline PCAN & Picus canus & 1 & 0 & 1 & 0 & 0 & 0 & 1 \\
\hline PCOL & Phylloscopus collybita & 3 & 3 & 6 & 3 & 4 & 7 & 13 \\
\hline PCRI & Parus cristatus & 0 & 2 & 2 & 3 & 2 & 5 & 7 \\
\hline PMAJ & Parus major & 3 & 5 & 8 & 3 & 1 & 4 & 12 \\
\hline PMOD & Prunella modularis & 3 & 1 & 4 & 4 & 4 & 8 & 12 \\
\hline PMON & Parus montanus & 0 & 3 & 3 & 0 & 0 & 0 & 3 \\
\hline PPAL & Parus palustris & 3 & 4 & 7 & 1 & 3 & 4 & 11 \\
\hline PPYR & Pyrrhula pyrrhula & 1 & 1 & 2 & 0 & 1 & 1 & 3 \\
\hline PSIB & Phylloscopus sibilatrix & 3 & 4 & 7 & 0 & 2 & 2 & 9 \\
\hline PTRO & Phylloscopus trochilus & 3 & 1 & 4 & 4 & 1 & 5 & 9 \\
\hline RIGN & Regulus ignicapillus & 0 & 0 & 0 & 3 & 3 & 6 & 6 \\
\hline RREG & Regulus regulus & 1 & 3 & 4 & 4 & 6 & 10 & 14 \\
\hline SATE & Sylvia atricapilla & 3 & 4 & 7 & 4 & 6 & 10 & 17 \\
\hline SBOR & Sylvia borin & 1 & 0 & 1 & 1 & 1 & 2 & 3 \\
\hline SCOM & Sylvia communis & 0 & 0 & 0 & 1 & 0 & 1 & 1 \\
\hline SEUR & Sitta europaea & 3 & 5 & 8 & 0 & 2 & 2 & 10 \\
\hline STOR & Saxicola torquata & 1 & 0 & 1 & 0 & 0 & 0 & 1 \\
\hline SVUL & Sturnus vulgaris & 1 & 0 & 1 & 0 & 0 & 0 & 1 \\
\hline TMER & Turdus merula & 3 & 5 & 8 & 4 & 6 & 10 & 18 \\
\hline TPHI & Turdus philomelos & 3 & 5 & 8 & 4 & 5 & 9 & 17 \\
\hline TPIL & Turdus pilaris & 0 & 1 & 1 & 1 & 0 & 1 & 2 \\
\hline TTRO & Troglodytes troglodytes & 3 & 4 & 7 & 4 & 6 & 10 & 17 \\
\hline TVIS & Turdus viscivorus & 3 & 4 & 7 & 4 & 4 & 8 & 15 \\
\hline
\end{tabular}

2 Table 3: List of bird species observed in Belgian Ardenne. Total is the total number

3 of forests (at silvicultural system level) where a given species was observed; Beech

4 and Conifer are respectively the number of beech or conifer forests where a given 
1 species was observed (beech+conifer=Total); the same for even-aged and uneven-

2 aged columns, splited according to tree species composition of the forests. 
1 Du Bus de Warnaffe, G. - Figure 1

2

3

4

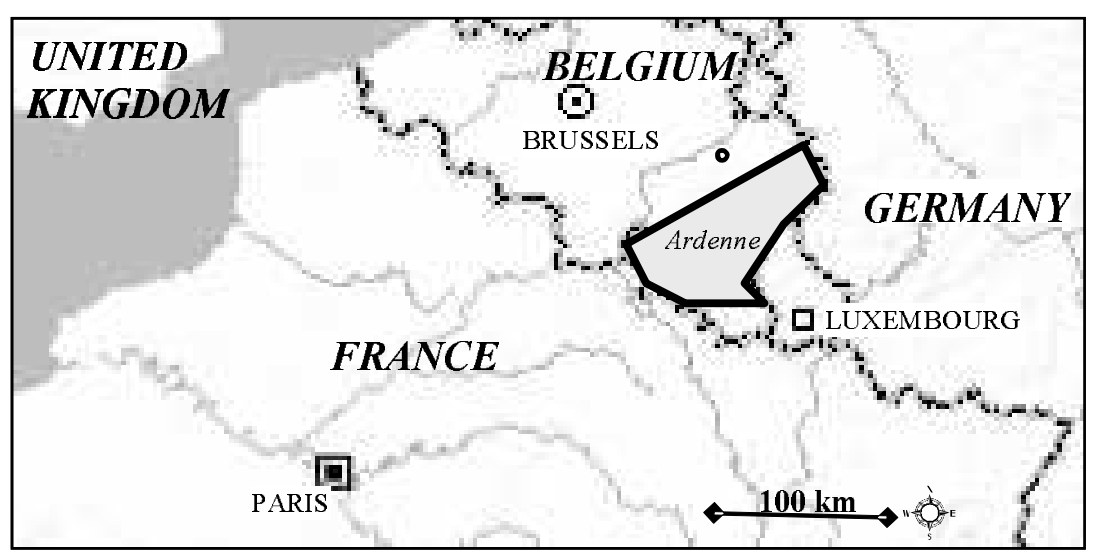

Figure 1. Study area: Ecological limits of the Belgian Ardenne (grey area with 11 solid lines). 
Du Bus de Warnaffe, G. - Figure 2

Plots in even-aged forests
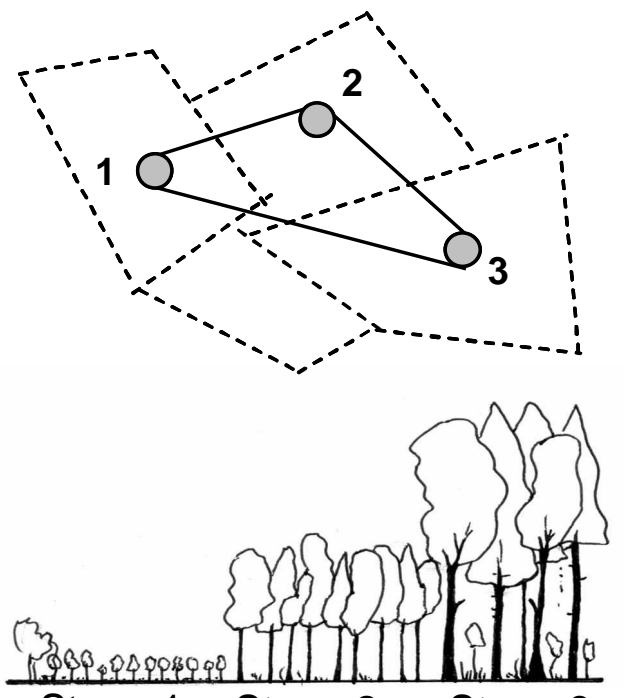

\section{Plots in uneven-aged forests}
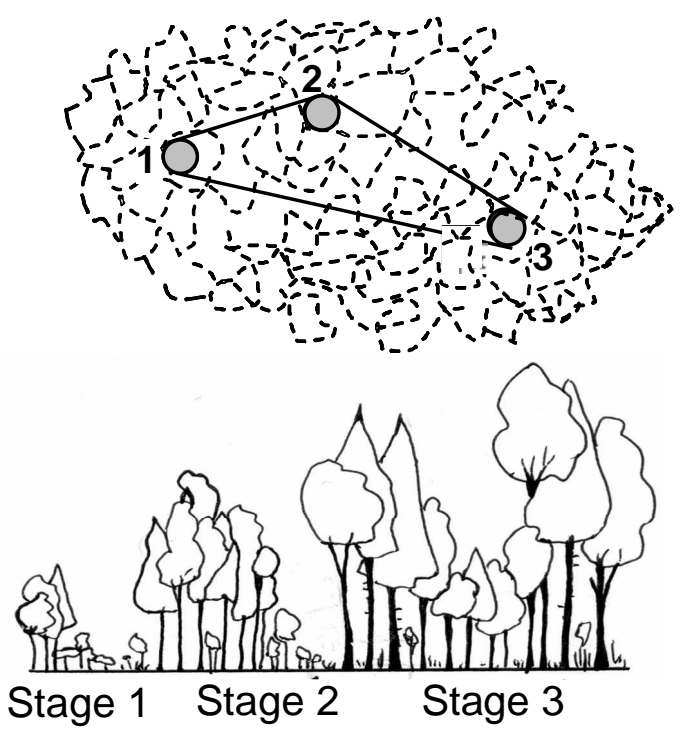

Figure 2. Scheme of the location of the plots in even-aged and uneven-aged forest areas, in aerial and field views. Broken lines define stands of different ages and/or tree composition, circles represent bird counting zones in plots $(25 \mathrm{~m}$ circle) and solid line convex hulls define the silvicultural system (about $15 \mathrm{ha}$ ). 

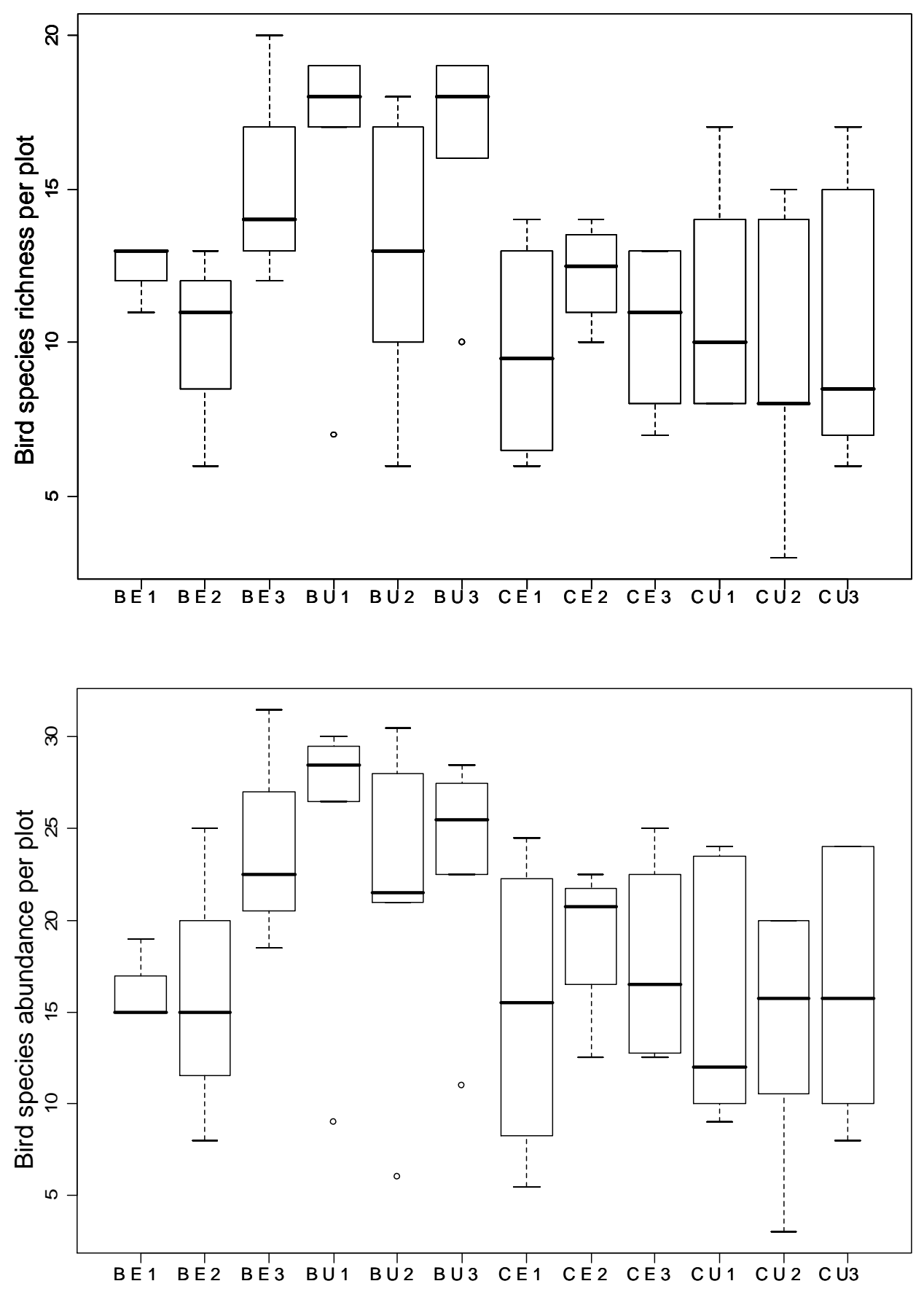

Figure 3. Box plots of the bird species richness (top) and abundance 8 (bottom) in sample plots according to tree species composition (B: beech or 9 C: conifer), cutblock size (E: even-aged or $U$ : uneven-aged) and stages (1, 2 or 3) 
2

3

4
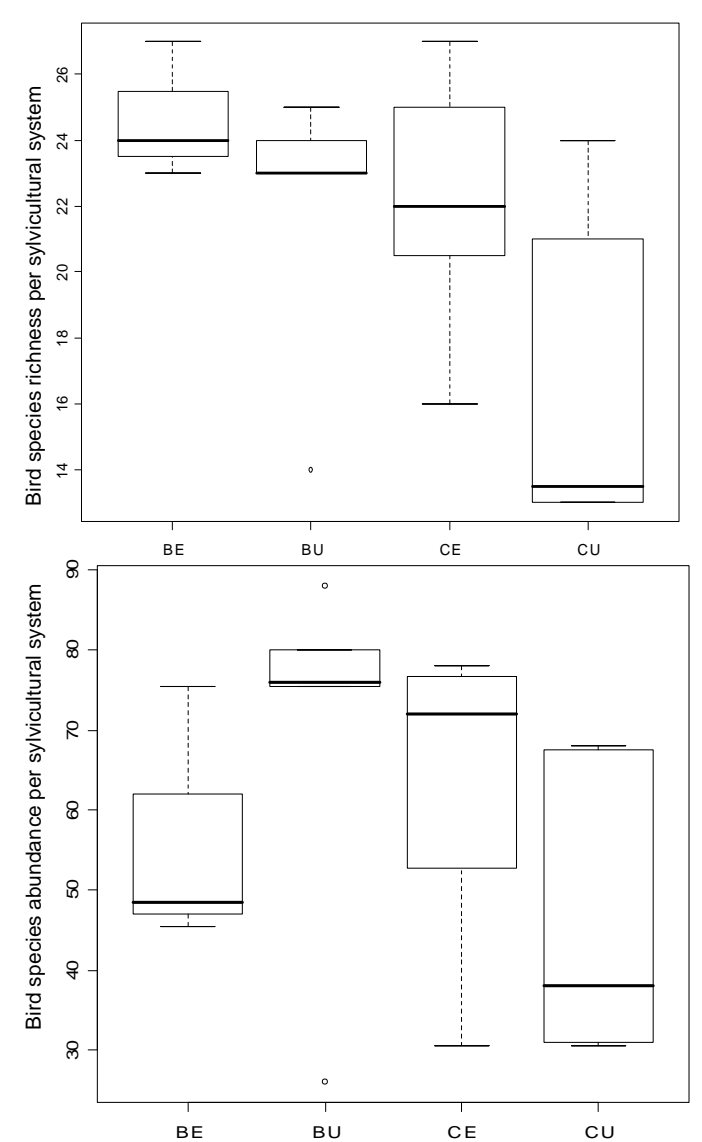

Du Bus de Warnaffe, G. - Figure 4
5
6

8

9

10

Figure 4. Box plots of the bird species richness (top) and abundance (bottom) in silvicultural systems according to tree species composition (B: beech or $\mathrm{C}$ : conifer) and cutblock size (E: even-aged or $\mathrm{U}$ : uneven-aged). 


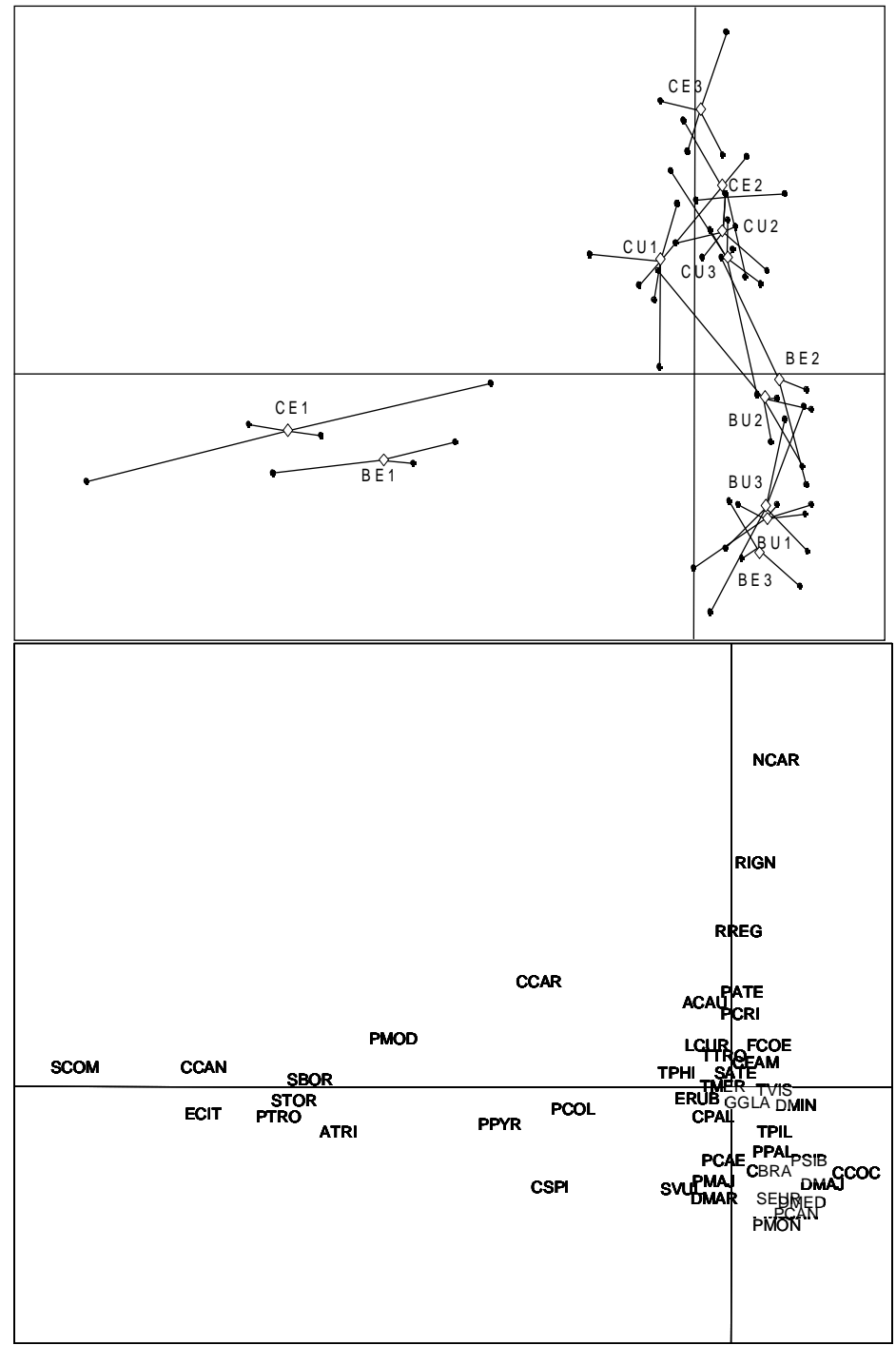

Figure 5 : Scatterplot of the between group analysis of the bird community data at the sample plot level. Top plot: sample plots (black dots) are linked to the mean position (diamond) of their silvicultural system and stage identified by the

7 following code: $\mathrm{EC}=$ Even-aged Conifer; $\mathrm{EB}=$ Even-aged Beech; $\mathrm{UC}=$ Unevenaged Conifer; UB = Uneven-aged Beech, the final number indicating the stage

9 (see text and Figure 2). Bottom plot: Ordination of the bird species on the same 10 axes. The code of the species is based on the first genus letter and the three lettres 11 of the scientific name (Table 3 ). Their positions have been slightly modified for a 
1 better readability. 
2
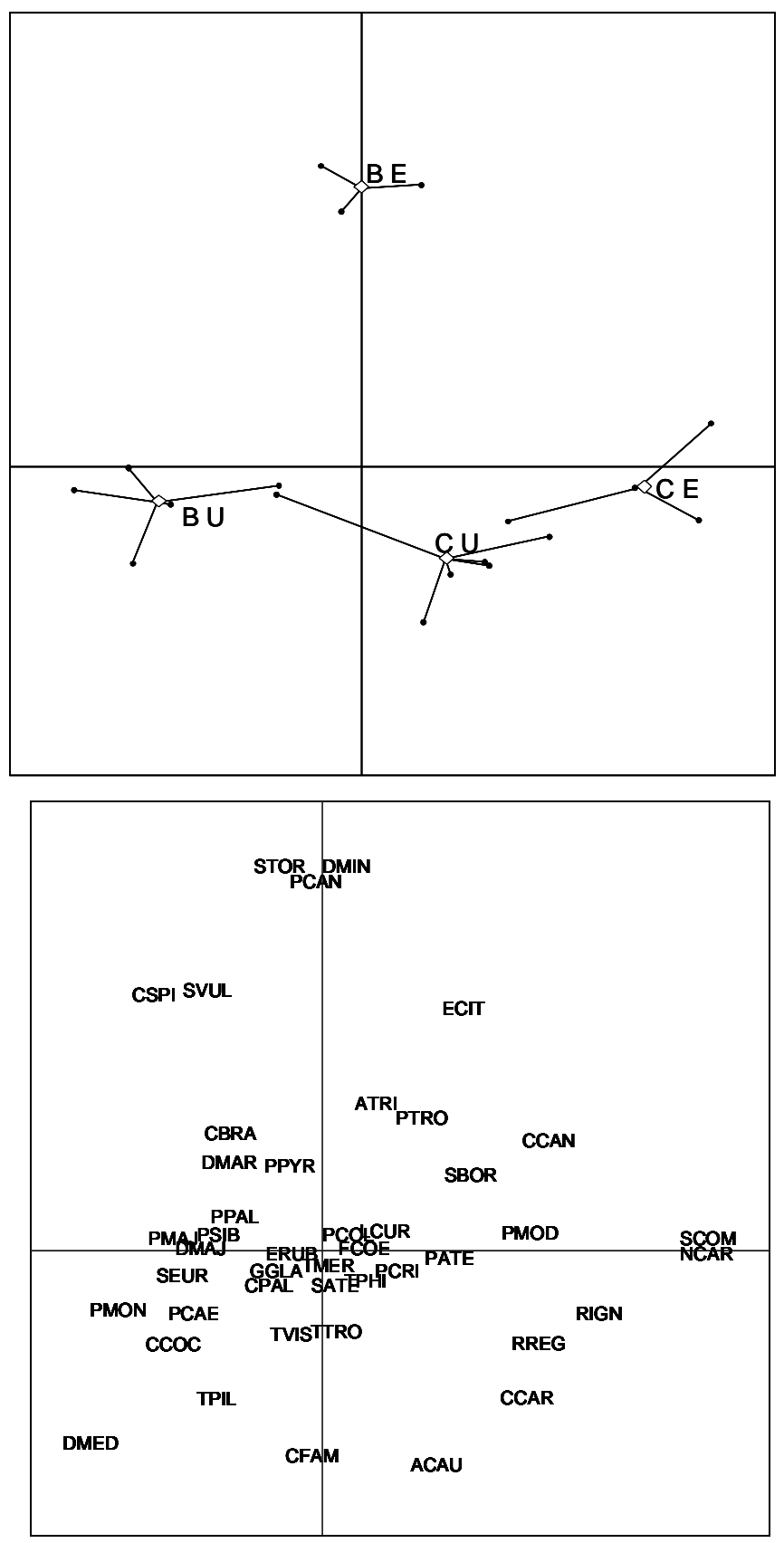

4 Figure 6 : Scatterplot of the between group analysis of the bird community data at 5 the silvicultural system level. Top plot: forest (black dots) are linked to the mean 6 position (diamond) of their silvicultural system identified by the following code: $7 \quad \mathrm{EC}=$ Even-aged Conifer; $\mathrm{EB}=$ Even-aged Beech; UC $=$ Uneven-aged Conifer; $8 \quad \mathrm{UB}=$ Uneven-aged Beech (see text and Figure 2). Bottom plot: Ordination of the 
1 bird species along the same axes. The code of the species is based on the first 2 genus letter and the three letters of the scientific name (Table 3). Their positions 3 have been slightly modified for a better readability. 